\title{
Physiological Study of Graft Union Formation in Cactus
}

\author{
II. Role of Auxin on Vascular Connection between Stock and Scion
}

\author{
Takashi Shimomura and Kenzo Fuzihara \\ College of Agriculture, University of \\ Osaka Prefecture, Sakai, Osaka
}

\begin{abstract}
Summary
Young seedlings of Notocactus submammulosus var. pampeanus cut transversely were placed onto transverse cut surfaces of young plants of Hylocereus trigonus. Vascular connection between stock and scion occurred in almost all grafts 20 days after grafting when cut ends of vascular bundles of stock and scion were placed together (Method I). When they were 1 or $3 \mathrm{~mm}$ apart transversely to each other (Method II or III), vascular connection occurred in only 40 or $10 \%$ of grafts.

By the Method II, NAA, IAA and 2,4-D promoted vascular connnection, and also increased the diameter of the vascular bundle connecting those of stock and scion. NAA (100 ppm) was most effective when applied three times every three days after grafting.

TIBA (0.1\% in lanolin), a well-known inhibitor of basipetal transport of auxin, inhibited vascular connection strongly. But, by subsequent NAA ( $0.01 \%$ in lanolin) applications, this inhibitory effect of TIBA was effaced completely.

When lanolin with NAA $(0.01 \%)$ was applied instead of a scion, it also induced a cambium in the area of the tissue between the lanolin and the vascular cut end of the stock.

The results suggested that the vascular connection in cactus grafts may be controlled by endogenous auxin of scions.
\end{abstract}

\section{Introduction}

Some attempts have been made to promote graft union formation by the application of auxins. Müller-Stoll (11, 12) used various methods to apply auxin for the grafting of grape vines, and showed that soaking of the cut ends of both stock and scion in a $0.05 \%$ solution of indoleacetic acid was the most effective treatment. A strong even ring callus was formed at the graft union. Similar results were reported by Kruyt (7) for certain decorative shrubs using naphthaleneacetic acid. These results show that graft union formation was promoted because of stimulation of callus formation by auxin. But, Ihara (5) and Kawahara (6) did not obtain such satisfactory results by application of auxin to some ornamental tree or herbal plant grafts.

Studies of xylem differentiation using budroot grafts of chicory (1), and bud-callus Received for publication December 26, 1975. grafts of some angiosperms (22) showed that grafted buds induced vascular differentiation in subjacent stock tissues. The studies also showed that vascular differentiation occurred when arxin was used instead of the buds.

Recently the authors made histological observations on graft union formation in cactus (17). The observations showed that the process of graft union formation consisted of the following two steps: i. callus formation by both cells just inside the cut surfaces of both stock and scion followed by callus cell adhesion between stock and scion; ii. formation of a connecting vascular bundle in the callus resulted in the vascular connection between stock and scion. The vascular connection occurred in $10 \%$ and $40 \%$ of grafts when the cut ends of vascular bundles of stock and scion were kept $3 \mathrm{~mm}$ and $1 \mathrm{~mm}$ apart transversely from each other respectively.

In the present study, the authors attempted to examine the effect of auxin exogenously 
applied to cactus grafts on the vascular connection and to determine whether the endogenous auxin of the scion may control the vascular connnection in cactus grafts.

\section{Materials and Methods}

Plant materials Seeds of Notocactus submammulosus var. pampeanus were soaked in $3 \%$ hydrogen peroxide for $24 \mathrm{hr}$ for surface sterilization and seed coat softening, and sown in a pot of sea sand in a green house. One week old seedlings about $2 \mathrm{~mm}$ in diameter were used as scions.

Young shoots of Hylocereus trigonus about $10 \mathrm{~cm}$ long collected from plants grown in a greenhouse were kept in a dark air-conditioned room at $25^{\circ} \mathrm{C}$ for rooting. When adventitious roots became visible on the cut surfaces of the shoots, the shoots were planted five to each in a $12 \mathrm{~cm}$-diameter pot of 1 part peat and 1 part sand and grown in a greenhouse.

Grafting methods The scion with its basal part cut transversely was placed onto the cut surface of the stock; the cut was mac'e $0.5-1.0 \mathrm{~cm}$ below the apex. At that time, the cut ends of the vascular bundles of both graft components were placed together (Method I) or $1 \mathrm{~mm}$ (Method II) and $3 \mathrm{~mm}$ (Method III) apart transversely from each other (Fig. 1). In this paper, Method II was used unless otherwise stated.

Grafts were grown in a growth room kept at $25 \pm 1^{\circ} \mathrm{C}$ in continuous lighting (200 lux at scions, Toshiba fluorescent coolwhite lamp) during the experiment.

Chemical treatment NAA (potassium- $\alpha-$ naphthaleneacetic acid) was dissolved in distilled water, and IAA (indoleacetic acid) and 2,4-

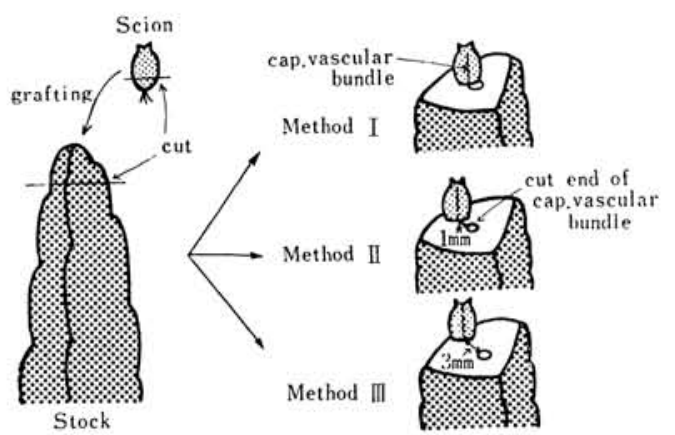

Fig. 1, A diagram of grafting methods in cactus.
D (2,4-dichlorophenoxyacetic acid) were dissolved in small amounts of ethyl alcohol (99.5\%) and appropriate amounts of distilled water were added to the solutions. A droplet $(0.005 \mathrm{~m} l)$ of a test solution or of distilled water as a control was applied to the apical portion of the scion with a $0.5 \mathrm{ml}$ plasticneedled syringe, one to three times after grafting.

Lanolin emulsions were prepared by stirring $1 \mathrm{~g}$ of melted lanolin with $0.5 \mathrm{~m} l$ of water. Some of the emulsion was left as it is, while some had $0.1 \%$ TIBA (2,3,5-triiodobenzoic acid) or $0.01 \%$ NAA dissolved in ethyl alcohol stirred into it. The ethyl alcohol was removed in these cases by heating.

The four chemical treatments were as follows. (1) Balls of plain lanolin $2 \mathrm{~mm}$ in diameter were placed one each on the apical portions of scions, and each lanolin ball was replaced 2 to 5 times every three days with a new one. (2) Balls with TIBA were used similarly. (3) Balls with TIBA were used similarly 3 times, then balls with NAA were additionally treated similarly 3 times. (4) The ball with TIBA was applied 6 times every three days afer grafting, and one day after each TIBA treatment a ball with NAA was also applied except for the final treatment of TIBA. Each ball applied as the final one was remained for 3 days and then removed.

In addition, to determine the effect of NAA on stock tissues, the lanolin balls with or without NAA were placed on cut surfaces of stock plants instead of scions and remained until the end of the experiment.

Histological observations Grafts were cut $0.5 \mathrm{~cm}$ below the graft union and excess tissues of stocks were trimmed off 20 days after grafting, unless otherwise stated. Trimmed samples were fixed, dehydrated, and embedded in paraffin. Embedded samples were sectioned longitudinally at $15 \mu \mathrm{m}$ with a rotary microtome, stained with Delafield haematoxylin or $0.1 \%$ toluidine blue $\mathrm{O}(15)$ in distilled water, and mounted with Canada balsam.

Measurement of scion growth The size of the scion in each sample sectioned was measured With a micrometer. Before the fixation, the number of areole, lateral bud-like organs with spines and hairs specific to cactus, 


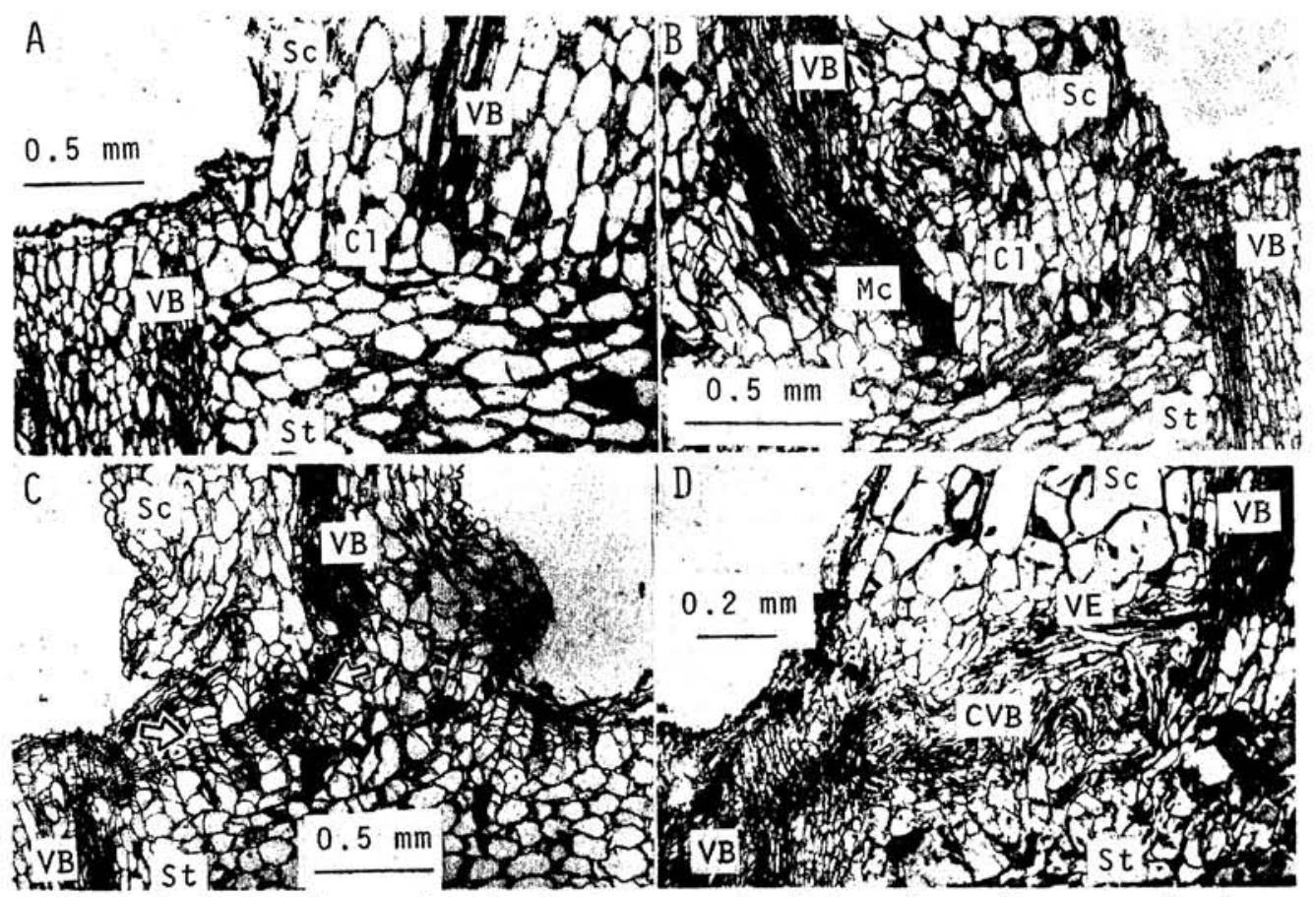

Fig. 2. Developmental stages of graft union in cactus grafts 20 days after grafting except for the case of (C), 13 days after grafting. Grafted with Method II, auxin not applied. (A) Stage A, only callus cell adhesion is completed between stock and scion; (B) Stage B, a meristematic cell nodule is observed to connect with the vascular bundle of the scion; (C) Cell divisions (arrows) between cut ends of stock and scion; (D) Stage C, a connecting vascular bundle (CVB) is formed between vascular bundles of stock and scion.

$\mathrm{Cl}$ : Callus, CVB : Connecting vascular bundle, Mc: Meristematic cells, Sc: Scion, St: Stock,

VB: Vascular bundle, VE: Vessel elements

was also counted under a stereo microscope.

\section{Results}

Histological observations The grafts of Method II with no chemical treatment showed the following pattern of graft union formation.

Two to four days after grafting, 1 to 3 layers of callus cells were formed inside the cut surfaces of stock and scion, then, they protoruded out of the surfaces and adhered to each other by the 6 days after grafting. In some grafts, further development past Stage A (shown in Fig. 2-A) of the graft union did not occur. In some other grafts, callus cells just under the vascular bundle of the scion divided, and then developed into a short meristematic cell nodule of ten contained a few vessel members, but did not develop further than Stage B (Fig. 2-B). The few remaining grafts completed the graft union, i.e., a strand of meristematic cells derived from the callus cells was formed between the vascular cut ends of graft components 10-12 days after grafting (Fig. 2-C). The meristematic cells differentiated into procambial cells and in succession, into vascular elements. Thus, the connection of vascular bundles of stock and scion was completed, Stage C (Fig. 2-D). Here, the newly formed vascular bundle is named a connecting vascular bundle (CVB).

The grafts of Method I and III showed the same pattern in graft union formation as the above.

Auxin applied to a scion did not stimulate callus formation strongly even when applied the day of grafting or 3 days after grafting, however, it promoted CVB differentiation and also increased the diameter of the CVB formed (Table 1). In addition, the CVB shape tended to become crooked or disorderly with the increase of auxin concentration and frequency 
Table 1. Effect of NAA application on the diameter of CVB, 20 days after grafting*.

\begin{tabular}{c|c|c}
\hline Treatment & $\begin{array}{c}\text { Mean diameter } \\
\text { of CVB }(\mathrm{mm})\end{array}$ & $\begin{array}{c}\text { No. of grafts } \\
\text { formed CVB }\end{array}$ \\
\hline Water control & 0.33 & 4 \\
NAA 100 ppm** & & \\
once & 0.43 & 9 \\
twice & 0.65 & 12 \\
three times & 0.68 & 19
\end{tabular}

* Same experiments as shown in Table 4.

** Applied 3 days after grafting; 3 and 6 days after grafting ; 3,6 , and 9 days after grafting respectively.

of auxin application (Fig. 3).

Application of TIBA followed by NAA the day after resulted in the increase of diameter of a vascular bundle, especially its lower part, of a scion. This enlarged vascular bundle was found to be composed of numerous small vessel elements and fusiformed meristematic cells (Fig. 4-A). In some cases, 1 or 2 adventitious root primordia were observed on a middle portion of a vascular bundle of a scion (Fig. 4-B). TIBA did not have an inhibitory effect on scion growth.

Scion growth NAA application resulted in an increase of scion growth, as measured 20 days after grafting. When $100 \mathrm{ppm}$ NAA was applied two or three times, scion growth and areole number were 2.5 fold and 2 or 3

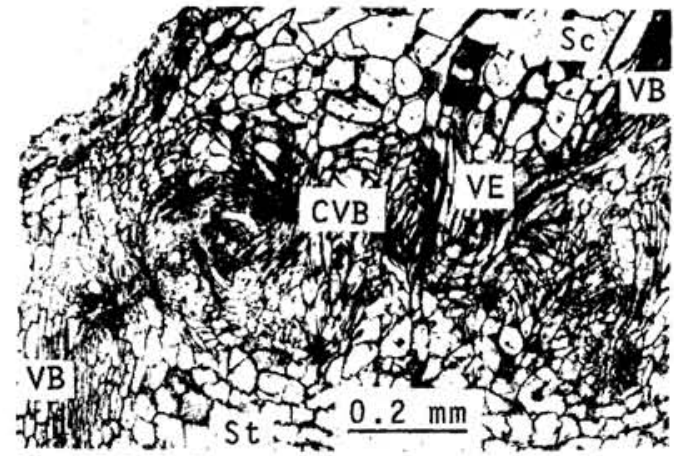

Fig. 3. Vascular connection in the graft on which auxin was applied, 20 days after grafting. The diameter of CVB is larger than that shown in Fig. 2-D. NAA (100 ppm) was applied on the 3 rd and 6 th day after grafting.

CVB: Connecting vascular bundle, Sc: Scion, St: Stock, VB: Vascular bundle, VE: Vessel elements

fold, respectively, as large as those without NAA (Table 2, Fig. 5).

Effect of auxin on vascular connection

(1) Effect of NAA concentration The ratio of grafts attained Stage $C$ to all surviving grafts (C-ratio) on the 20 days after grafting was only $40 \%$ when NAA was not applied. NAA of every concentration resulted in the increase of this ratio to $90-100 \%$ (Table 3 ). The use of $1,000 \mathrm{ppm}$ NAA had a remarkable

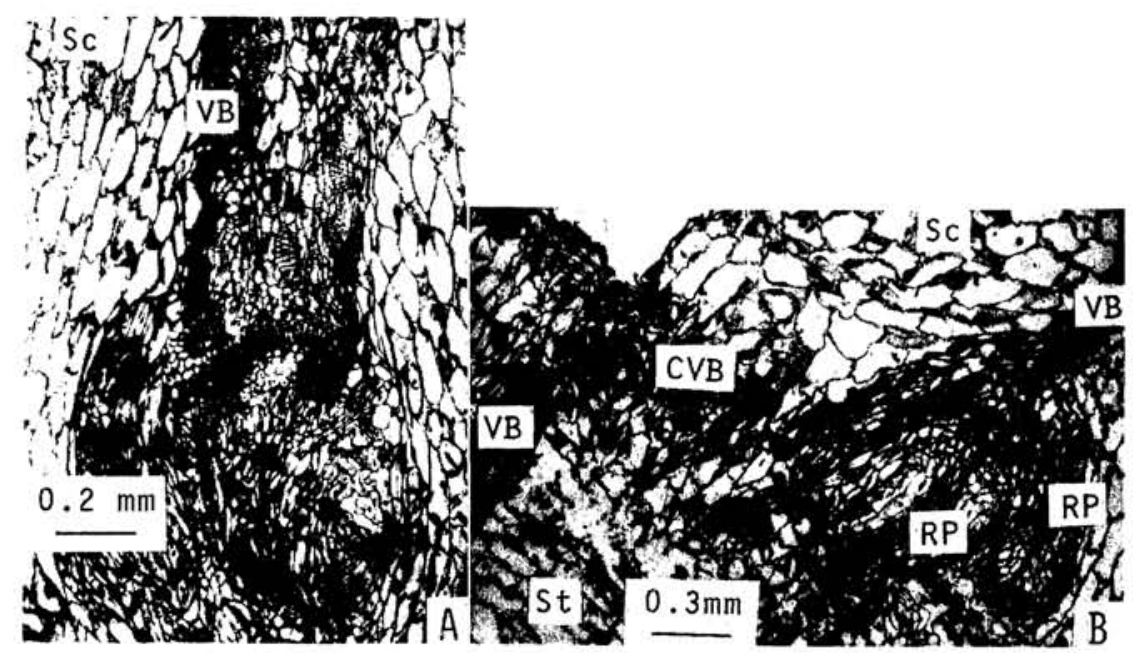

Fig. 4. Responses of grafts to alternative applications of TIBA (6 times every three days after grafting) and NAA ( 5 times every three days after the 4 th day of grafting), 20 days after grafting. (A) An enlarged vascular bundle of the scion containing numerous vessel elements and fusiformed cells; (B) adventitious root primordia are observed on the middle portion of the vascular bundle of the scion.

CVB : Connecting vascular bundle, RP: Root primordia, Sz: Scion, St: Stock, VB: Vascular bundle 
Table 2. Effect of NAA application on growth and areole number of the scion, 20 days after grafting

\begin{tabular}{l|c|c}
\hline \multicolumn{1}{c|}{ Treatment } & $\begin{array}{c}\text { Growth of scion* } \\
\mathrm{mm}^{2}(\%)\end{array}$ & $\begin{array}{c}\text { No. of areoles* } \\
\text { of scion }\end{array}$ \\
\hline Water control & $4.7(100)$ & 1.7 \\
NAA** & & \\
$\quad$ once & $7.3(156.8)$ & 3.1 \\
$\quad$ twice & $9.4(202.6)$ & 5.2 \\
three times & $8.3(187.7)$ & 3.9 \\
\hline
\end{tabular}

* Mean values of $13,16,15$, and 19 grafts from the top to the bottom.

** 100 ppm NAA was applied, 3 days after grafting ; 3 and 6 days after grafting; 3,6 , and 9 days after grafting respectively.

\section{CONTROL ONCE TWICE 3 TIMES}



Fig. 5. Comparison of scion growth between grafts with and without NAA (100 ppm), 20 days after grafting. Areoles (arrow) are shown on the scion. Sc : Scion, St : Stock

effect on CVB differentiation, but also brought about an inhibition of scion growth. And 10 ppm NAA was not so reliable in causing the strong CVB differentiation. From the results, NAA was used in $100 \mathrm{ppm}$ in all subsequent experiments.

(2) Effect of frequency and timing of NAA applicaiton NAA was applied once (the day of grafting, 3,6 , or 9 days after grafting), twice ( 3 and 6 days after grafting), and three times $(3,6$, and 9 days after grafting). NAA increased the $\mathrm{C}$-ratio in every experiment, although a single application made 9 days after grafting had not such a strong effect (Table 4). NAA was most effective when applied three times.

(3) Effect of various kinds of auxin IAA and 2,4-D applied three times were also effective in promoting CVB differentiation. Compared to $25 \%$ in the $\mathrm{C}$-ratio for the water control, IAA (100 ppm) gave $93 \%$ and $2,4-\mathrm{D}$ $(20 \mathrm{ppm})$ gave $83 \%$.

(4) Effect of NAA in the case of Method III Although the C-ratio was ca. 9\% without NAA application, it was increased to $80 \%$
Table 3. Effect of NAA concentration on vascular connection, 20 days after grafting.

\begin{tabular}{r|c|c|c|c}
\hline \multirow{2}{*}{ Treatment } & \multicolumn{3}{|c|}{$\%$ of grafts at } & $\begin{array}{c}\text { No. of } \\
\text { total } \\
\text { grafts }\end{array}$ \\
\cline { 2 - 4 } & Stage A & Stage B & Stage C & \\
\hline Water control & 11.1 & 44.4 & 44.4 & 9 \\
NAA* $^{*} 10 \mathrm{ppm}$ & 12.5 & 0 & 87.5 & 8 \\
$100 \mathrm{ppm}$ & 0 & 0 & 100 & 11 \\
$1,000 \mathrm{ppm}$ & 0 & 0 & 100 & 9 \\
\hline
\end{tabular}

Fifteen grafts in each experiment, and some grafts failed in cell adhesion were omitted from them. Grafted with Method II.

* Applied three times, 3, 6, and 9 days after grafting.

Table 4. Effect of frequency and timing of NAA application on vascular connection, 20 days after grafting.

\begin{tabular}{c|c|c|c|c}
\hline \hline \multirow{2}{*}{ Treatment } & \multicolumn{3}{|c|}{$\%$ of grafts at } & $\begin{array}{c}\text { No. of } \\
\text { total } \\
\text { grafts }\end{array}$ \\
\cline { 2 - 5 } & Stage A & Stage B & Stage C & 13 \\
Water control & 53.8 & 15.4 & 30.8 & 13 \\
NAA 100 ppm & & & & \\
once & & & & \\
$0 *$ & 30.8 & 0 & 69.2 & 13 \\
3 & 16.7 & 8.3 & 75.0 & 12 \\
6 & 10.0 & 0 & 90.0 & 10 \\
9 & 27.3 & 18.2 & 54.5 & 11 \\
twice** & 0 & 20.0 & 80.0 & 15 \\
three times*** & 0 & 0 & 100 & 19 \\
\hline
\end{tabular}

Fifteen to twenty grafts were used, and some grafts failed in cell adhesion were omitted from them. Grafted with Method II.

* Days after grafting.

** Applied 3 and 6 days after grafting.

*** Applied 3, 6, and 9 days after grafting.

by three time applications of NAA.

(5) Effect of NAA on promotion of CVB differentiation Grafts treated with or without NAA were collected $7,9,13,20$, and 40 days after grafting to examine the developmental stage of the graft union. When NAA was not applied, CVB differentiation did not begin until 13 days after grafting. In contrast, NAA applied 3 and 6 days after grafting advanced the beginning of CVB differentiation to 7 days after grafting. By 9 days after grafting, the C-ratio reached its peak value, the same as that obtained 20 days after grafting (Table 5).

Inhibition of vascular connection by TIBA and release from it by NAA

(1) The case of Method I TIBA (0.1 
Table 5. Effect of NAA on the formation of vascular connection between stock and scion.

\begin{tabular}{c|c|c|c|c|c}
\hline \multirow{2}{*}{ Treatment } & $\begin{array}{c}\text { Days of } \\
\text { observations } \\
\text { after grafting }\end{array}$ & \multicolumn{2}{|c|}{$\begin{array}{c}\text { \% of grafts at } \\
\text { A }\end{array}$} & $\begin{array}{c}\text { No. of } \\
\text { total } \\
\text { totage } \\
\text { grafts }\end{array}$ & $\begin{array}{c}\text { Stag } \\
\text { C }\end{array}$ \\
\hline Water control & 7 & 100 & 0 & 0 & 11 \\
& 9 & 77.7 & 22.3 & 0 & 9 \\
& 13 & 33.3 & 33.3 & 33.3 & 9 \\
& 20 & 46.1 & 23.1 & 30.8 & 13 \\
& 40 & 53.3 & 26.7 & 20.0 & 15 \\
\hline NAA* 100 ppm & 7 & 22.2 & 11.1 & 66.7 & 9 \\
& 9 & 20.0 & 0 & 80.0 & 10 \\
& 13 & 14.3 & 0 & 85.7 & 14 \\
& 20 & 0 & 12.7 & 87.3 & 15 \\
& 40 & 7.7 & 7.7 & 84.6 & 13 \\
\hline
\end{tabular}

Fifteen to twenty grafts were used, and some grafts failed in cell adhesion were omitted from them. Grafted with Method II.

* NAA was applied twice, 3 and 6 days after grafting.

Table 6. Inhibitory effect of TIBA on vascular connection and antagonistic effect of NAA, by the case of Method I.

\begin{tabular}{l|c|c|c|c}
\multirow{2}{*}{ Treatment } & \multicolumn{3}{|c|}{$\%$ of grafts at } & $\begin{array}{c}\text { No. of } \\
\text { total } \\
\text { grafts }\end{array}$ \\
\cline { 2 - 5 } & Stage A & Stage B & Stage C & 16 \\
\hline $\begin{array}{c}\text { Control } \\
\text { (Plain lanolin) }\end{array}$ & 0 & 25.0 & 75.0 & 16 \\
$\begin{array}{c}\text { TIBA* } \\
\text { 3 times } \\
\begin{array}{c}\text { TIBA* } \\
3 \text { times }\end{array}\end{array}$ & 20.0 & 60.0 & 20.0 & 15 \\
$+\begin{array}{c}\text { NAA** } \\
\text { 3 times }\end{array}$ & 6.7 & 13.3 & 80.0 & 15 \\
\hline
\end{tabular}

Eighteen grafts in each experiment, and some grafts failed in cell adhesion were omitted from them. Examined 20 days after grafting.

* TIBA (0.1\% in lanolin) applied every three days after grafting.

** NAA $(0.01 \%$ in lanolin) applied every three days after the final treatment of TIBA.
Table 7. Effect of TIBA on vascular connection, applied exclusively, alternately with or previous to NAA application, 20 days after grafting.

\begin{tabular}{|c|c|c|c|c|}
\hline \multirow{2}{*}{ Treatment } & \multicolumn{3}{|c|}{$\%$ of grafts at } & \multirow{2}{*}{$\begin{array}{c}\text { No. of } \\
\text { total } \\
\text { grafts }\end{array}$} \\
\hline & Stage A & Stage B & Stage C & \\
\hline $\begin{array}{l}\text { Control } \\
\text { (Plain lanolin) } \\
\text { a. TIBA* }\end{array}$ & 61.3 & 0 & 35,7 & 14 \\
\hline $\begin{array}{l}3 \text { times } \\
\text { b. TIBA* }\end{array}$ & 53.8 & 38.7 & 7.7 & 13 \\
\hline $\begin{array}{ll} & 6 \text { times } \\
\text { c. } & a+\mathrm{NAA}^{* *}\end{array}$ & 43.7 & 56.3 & 0 & 16 \\
\hline $\begin{array}{l}3 \text { times } \\
\text { d. } \quad \mathrm{b}+\mathrm{NAA}^{* *}\end{array}$ & 6.6 & 46.7 & 46.7 & 15 \\
\hline 5 times & 5.9 & 23.5 & 70.6 & 17 \\
\hline
\end{tabular}

Twenty grafts in each experiment, and some grafts failed in cell adhesion were omitted from them. Grafted with Method II.

* $0.1 \%$ TIBA (in lanolin) applied every three days after grafting.

** $0.01 \%$ NAA (in lanolin) applied : a. every three days after the final application of TIBA; b. alternately with TIBA every three days after the 5 th day after grafting.

$\%$ in lanolin) inhibited vascular connection when applied three times every three days after grafting, although the $\mathrm{C}$-ratio was $75 \%$ in the case of the plain lanolin treatment (Table 6 ). The $\mathrm{C}$-ratio reached $80 \%$ when NAA was applied three times after the TIBA applications (Table 6).

(2) The case of Method II The C-ratio was $7.7 \%$ or $0 \%$ when TIBA was applied 3 or 6 times, while plain lanolin treatment gave $35.7 \%$ (Table 7). NAA, however, increased the C-ratio to ca. $47 \%$ when applied three times after TIBA applications (Table 7). In

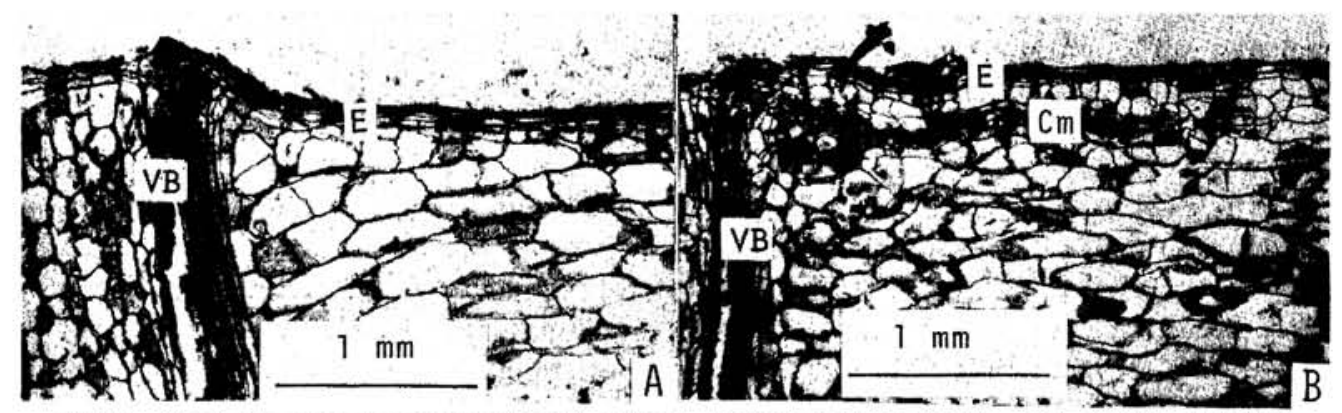

Fig. 6. Responses of tissues just under cut surfaces of stock plants to lanolin with or without $0.01 \%$ NAA, 12 days after treatment. (A) The case of plain lanolin; (B) the case of lanolin with NAA. A cambium containing a few vessel elements is observed. E : Epidermis, VB : Vascular bundle 
addition, TIBA did not inhibit the vascular connection when applied alternately with NAA in the way described above (Table 7).

Effect of NAA in lanolin put on cut surfaces of stocks

Lanolin ball with or without NAA was placed on a cut surface of a stock plant three days after cutting. The stock plants were collected 12 days after the treatment and prepared for microscopic observations.

The cut surface of the stock plant consisted of thin layer of dead cells, and was covered with lignin-like components. Beneath thin layer of dead cells, a zone of epidermal cells in layers three to six were observed. It may be made by periclinal divisions of parenchymatous cells. No other structural change was observed by the treatment of the plain lanolin (Fig. 6-A).

In contrast, $0.01 \% \mathrm{NAA}$ induced a cambium parallel to the epidermis in the $3 \mathrm{rd}$ to 5 th layer of the parenchymatous cell layer. This cambium contained a few vessel elements, and was connected with the cut end of the vascular bundle of the stock plant (Fig. 6-B).

\section{Discussion}

The statement is often made that for successful grafting cambium layers of stock and scion must be matched, and two badly matched cambium layers may delay the graft union or, if extremely mismatched, prevent graft union (4). In cactus grafts, that is the case, and is described in this paper as Stage A or $\mathrm{B}$ in Method II or III. However, auxin showed remarkable success in promoting the vascular connection between stock and scion. And it must be noted that auxin was applied on the apical portion of the scion in the present study. This method differs from those used by many workers $(5,6,7,11,12)$ who did not succeed in promoting the vascular connection by auxin application.

It is widely recognized that auxin is a controlling factor in the differentiation of vascular tissues of higher plants (14). Auxins such as IAA, NAA, and 2,4-D as well as endogenous auxin are known to move basipetally in plant tissues (3). Morris et al. (9) found that IAA applied to apices intact, lightgrown dwarf pea seedlings was transported unchanged to the root system. In the present study, auxins applied to scions or directly applied to the cut surfaces of stock plants induced the differentiation of vascular tissues or cambiums containing a few vessel elements. It is possible that auxin applied to the top portions of scions reached callus tissues passing through the vascular bundles of scions and induced CVB differentiation in callus tissues. However, there is the question of why a new vascular bundle or a cambium is formed only between the cut ends of vascular bundles of stock and scion or between the cut end of the stock's vascular bundle and the lanolin ball with NAA. To solve this problem, the distribution and movement of ${ }^{14} \mathrm{C}-\mathrm{NAA}$ in the stock and scion is being investigated.

In experiments on differentiation of wound vessel members (WVM) in Coleus, Thompson and Jacobs (20) found that $0.1 \%$ TIBA in lanolin applied as a ring around the stem above the wound highly inhibited the WVM differentiation, and mentioned that the TIBAinduced inhibition of WVM differentiation supported the TIBA blockage of basipetal IAA transport hypothesis. In the present study, $0.1 \%$ TIBA in lanolin applied to the top portion of the scion also inhibited CVB differentiation. This inhibitory effect of TIBA on CVB differentiation may be due to blocking polar auxin transport $(3,10,13)$. So, it is possible that endogenous auxin of a scion acts as a controlling factor of CVB differentiation in cactus grafts. On the basis of this hypothesis, it may be that a cause of the delay or prevention of the vascular connection mentioned above (Stage A or B) is that the auxin concentration reaching the callus is insufficient to induce CVB differetiation in such a wide area ( 1 or $3 \mathrm{~mm}$ ) of the callus.

Sargent and Wangermann (16) found that IAA or NAA had little effect on the amount of vascular tissue in Lemna minor but increased orderly vascular tissue when applied in combination with TIBA. And they concluded that an unknown inhibitor of vascular differentiation is present in the fronds and that this inhibitor is specifically counterracted by TIBA. Concerning these Sargent and Wangermann's results, Sorokin and Thimann (18) mentioned "A more probable explanation of 
the synergism would be that the TIBA was exerting its well-known inhibiting effect on auxin transport, so that the auxins taken up became accumulated in or near the vascular tissue, and hence more powerfully stimulated its further differentiation". This explanation seems to be quite suitable for results of the present study, i.e., TIBA applied alternately with NAA increased the amount of vessel elements and fusiformed-meristematic cells in the scion's vascular bundle.

In the study of xylem differentiation, there is a problem whether the differentiation preceeds or follows the cell divisions. Fosket (2) reviewed the relationship between cell division and WVM differentiation in cultured stem explants of Coleus, and gave presumptive evidence that either DNA synthesis or mitosis is a prerequisite to xylem differentiation. Subsequently, studies supporting Fosket's view have been performed $(8,19,21)$. The results of the present study substantiate this idea with respect to CVB differentiation: Initial division of callus cell was required for subsequent differentiation of vessel elements in CVB of cactus grafts.

It is possible that the NAA applied increased the size and areole number of the scion through advancing the time of vascular connection, because intact Notocactus seedlings did not show such a vigorous growth by the NAA application.

In the present study, some grafts failed in cell adhesion in each experiment. Auxin applied, however, did not affect cell adhesion. The causes and mechanisms of failure in cell adhesion should also be studied.

The present study showed that the application of exogenous auxin promoted vascular connection and that endogenous auxin of the scion may be a controlling factor of vascular connection in cactus grafts. On the basis of this finding, further study will show practical benefits from using auxin to stimulate vascular connection, thereby facilitating the graft union formation of stock-scion combinations considered to be difficult.

\section{Acknowledgment}

The authors benefited from helpful discussions and suggestions of Professor Y. Saka- nishi, College of Agriculture, University of Osaka Prefecture, and Professor T. Nakazima, College of Agriculture, Tokyo University.

\section{Literatura Cited}

1. Camus, G. 1949. Recherches sur le role des burgeons dans les phénomènese de morphogénèse. Rev. Cytol. Veg. 9: 1-199.

2. FOSKET, D.E. 1968. Cell division and differentiation of wound-vessel members in cultured stem segments of Coleus. Proc. Nat. Acad. Sci. U.S. A. $59: 1089-1096$.

3. Goldsmith, M. H. M. 1968. The transport of auxin. Ann. Rev. Plant Physiol. 19:347360 .

4. HartmanN, H.T., and D.E. Kester 1975. Plant Propagation (3 rd edn.). Prentice-Hall, New Jersey.

5. IHARA, Y. 1968. Studies on the grafting of some ornamental trees (in Japanese). Doctoral thesis, Kyoto University.

6. Kawahara, H. 1954. Studies on the tissue differe ntiation in the callus of harbal plant grafts (in Japanese English summary). Sci. Rep. Fac. Agr. Ibaraki University. 2: 1-8.

7. KRUYT, W. 1847. The effect of growth substances, vitamins, traumatic acid, ethylenechlorbydrin and warm water on the grafting of some ornamental plants (in Dutch). Nederland Dendrol. Vereen., Yaarboek, 16: 83-109.

8. Mizuno, K.,A. Komamine, and M. SHimokoriYAMA. 1971. Vessel element fomation in cultured carrot-root phloem slices. Plant Cell Physiol. $12: 823-830$.

9. MORRIS, D. A., R.E. BRIANT, and P.G. THOMSON. 1969. The transport and metabolism of ${ }^{14} \mathrm{C}$-labelled indoleacetic acid in intact pea seedlings. Planta (Berl.). 89 : 178-197.

10. —, and G. O. KADIR. 1972. Pathways of auxin transport in the intact pea seedling (Pisum sativum L.). Planta (Berl.). 107 : 171-182.

11. MüLLER-SToll, W.R. 1938. Versuche über die Verwendbarkeit der $\beta$-Indolylessigsäure als verwachsungsförderundes Mittel in der Rebenveredlung. Angew. Bot. $20: 218-238$.

12. 1940. Weitere Versuche über die Verseudbarkeit von Wuchstoffen in der Rebenveredlung. Gartenbauwiss. $14: 151-$ 168.

13. Niedergang-Kamien, E., and A. C. Leopold. 1957. Inhibitors of polar auxin transport. Physiol. Phlant. $10: 29-38$.

14. ROBERTS, L.W. 1968. The initiation of xylem differentiation. Bot. Rev. $35: 210-250$. 
15. SAKAI, W.S. 1973. Simpled metho for differential staining of paraffin embedded material using toluidine blue O.Stain Technol. 48 : $247-249$.

16. SARgent, J. A., and E. WANGERMAnN. 1958. The effect of some growth regulators on the vascular system of Ldmna minor. New Phytologist. $58: 345-363$.

17. SHImomura, T. and K. FUZiharA, 1976. Histological observations of graft unionformation in cactus (in Japanese. English summary). J. Jap. Soc. Hort. Sci. $44: 402-408$.

18. SOROKIN, H.P., K. V. THIMANN. 1964. The histological basis for inhibition of axillary buds in Pisum sativum and the effects of auxins and kinetin on xylem development. Plotoplasma. $59: 326-350$.
19. Sussex, I. M., M. E. Clutter, and Goldsmith, M. H. M. 1972. Wound recovery by pith cell redifferentiation: Structural chenges. Amer. J. Bot. $59: 797-804$.

20. THOMPSON, N.P., and W.P. JACOBS. 1966. Polarity of IAA effect on sieve-tube and xylem regeneration in Coleus and tomato stems. Plant Physiol. $41: 673-682$.

21. TORREY, J.G., and D. E. Fosket. 1970. Cell division in relation to cytodifferentiation in cultured pea root segments. Amer. J. Bot. $57: 1072-1080$.

22. WETMORE, R. H., and J.P. RIER. 1963. Experimental induction of vascular tissue in the callus of angiosperms. Amer. J. Bot. 50 : $418-430$. 


\title{
サボテンにおける接ざ木ゆ合の生理学的研究（第 2 報）
}

穂木, 台木間の維管束連絡に対するオーキシンの役割

\author{
下村 孝・跑士原健三 \\ (大服府立大学紫学部)
}

\begin{abstract}
摘 要
シシオウマル (Notocatus submammulosus var. pampeanus) の発芽 1 週間目の苗を基部で切断し, サン カクチュウ (Hylocereus trigonus) の插し木苗の水平切 訴面上に乘せて茲ぎ木した，両者の維管束の切断面を合 わせて按ぎ木した場合 (Method I)，20 日目にはほぼ 100\% の個体で維管束速絡が完成されるが, 蓝方问に 1 mm (Method II), あるいは $3 \mathrm{~mm}$ (Method III) ずら せて接ぎ木すると $40 \%$ あるいは $10 \%$ の個体でしか維 管束連絡は起らない.この維管束連絡に対するオーキシ ソ, TIBA の影㗽を調ベることにより, 㮩木内生オーキ シンの役割を検討した. 接ぎ木方法には主として Method II を用いた.

$10 \sim 1,000 \mathrm{ppm}$ の NAA 水溶波を接き木後 2 日打きに 3 回稳木頂端に滴下処理すると, 約 $90 \%$ の個体で維管 束速絡が起り，対典区の $40 \%$ を大きく上まわったし


は, 稳木と台木の維管束をむすぶ速絡維管束の形成が他 の場合に比べて铃弱になった.

$100 \mathrm{ppm} \mathrm{NAAを1}$ 回（接ざ木後 $0,3,6$ または 9 日 日), 2 回（接ぎ木後 3 および 6 日目）さらに 3 回（搭 ぎ木後 3,6 拉よび 9 日目) 処理した場合，いずれの処 理でも維管束連絡の制命は大となったが， 3 问処理がも っとも効果的であった。

NAA の代りに IAA (100 ppm) p 2, 4-D (20 ppm)

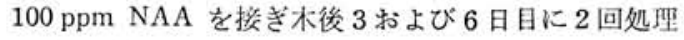
して連絡維管束の分化時期を調べると，対照区ては接ぎ 木後 13 日目以降に起こる分化が NAA 処理によって 7 日目まで早められることがわかった

接ぎ木後 20 日目に調枉すると, NAA 処理区での䅹 木の生長 [大きさ, 刺座 (側芽) の数]も対照区に比へ て大であった.

馛木の代りに NAA (0.01\%) を含むラノリンを台术 の切断面に乘せると，15 日目には切断面下に再生した装 皮淔下の柔組織内に, 維管束の切断面と連絡する形成層 が分化した。

TIBA $(0.1 \%)$ を含むラノリンを, 接木後 3 日目こと に 3 および 6 回穂木頂端に処理すると, 維管束連絡にい たる個体は $7.7 \%$ および $0 \%$ にすぎず対照区での価を 下まわったまな Method I の場合には勄処理で 75\% の個体で維管束連絡が起こるのに, TIBA (0.1\%) の 3 回处理でその価は $20 \%$ にまで減少した.

TIBA の維管束速絡に対する抑制効果は TIBA 処理 後あるいは TIBA と交互に行った NAA 処理によって 打ら消されて，いずれの場合にも50 80\% の個体で維 管東連絡が起った.

以上の結果から，サポテンの接ぎ木では維管束連絡を 支配している要因の一つが穗木内生のオーキシンである と考えられた。
\end{abstract} の水溶液を用いても NAA と同様の効果が得られた. 